\title{
COMPARATIVE ANALYSIS OF CONSTITUTIONAL RESPONSIBILITY OF THE GOVERNMENT FOR EQUALIZATION OF REGIONAL DISPARITIES
}

\author{
Antun MARINAC \\ Senior lecturer, Polytechnic of Požega, Croatia \\ E-mail: amarinac@vup.hr
}

\begin{abstract}
The paper focuses on a comparative analysis of the responsibility of authorities to act on equalizing regional disparities, starting from the principle of equality. In addition to regional disparities and the principle of equality, two key concepts of work (responsibility and efficiency of the authorities) are viewed in the context of the general theory of constitutional law. The starting point of the paper is the perception of regional disparities that are defined as a multiple problem in the territorial-political community. This points to the fact that regional disparities are the reason for public authorities to act in the direction of their equalization.

The next chapter analyzes the role of the constitution in resolving regional disparities and lists several constitutional functions that encourage the uniformity of regional development.

The fourth, the most comprehensive and most important chapter analyzes the constitutional responsibility of the authorities to equalize regional disparities in different countries (the Republic of Croatia, Slovenia, Northern Macedonia, Montenegro, Serbia, Italy, Spain, the Federal Republic of Germany and Switzerland).

The paper is based on the following hypotheses:

H1: Although cohesion policy at the EU level aims at reducing regional disparities through shared competences between Member States and the EU, some Member States also express constitutional requirements for equalizing regional disparities; $\mathrm{H} 2$ : Constitutional basis of the government's responsibility for equalizing regional disparities exists in different countries, regardless of their government system;

H3. Effectiveness of public authorities in terms of equal development and living conditions within a national territory shows significant differences from state to state.
\end{abstract}

Key words: efficiency, equality, regional disparities, constitution, constitutional responsibility. 


\section{Introduction}

In the coexistence of all citizens in a territorial - political community, one of the important issues of common interest is the issue of balanced development of all parts of the community. The challenges of public authorities' actions to equalize regional disparities have become widespread requirements in constitutions as fundamental acts of territorial-political communities. In this regard, they call for joint and well-coordinated action by all relevant stakeholders in the regional development process. The paper does not deal with disparities between individuals (rich and poor citizens), but with development disparities between territorial units. In addition, as a rule, groups of poor citizens live in underdeveloped territorial units.

Regarding research methodology, the following methods will be used: a) method of analysis (analysis of the responsibility of authorities in equalizing regional disparities), b) normative method (responsibility of government institutions for balanced development is normatively prescribed in basic acts at: European, national (constitutions and laws) ) and regional and local level, c) secondary research (discoveries from the literature), d) comparative method (comparison of constitutional responsibility in different European countries), e) historical method (consideration of historical examples of the development of institutional responsibility) and f) statistical method (statistical data is a good indicator of regional disparities since it show the state of development of individual areas).

The responsibility of government holders to equalize regional inequalities is discussed in terms of the general theory of constitutional law. In doing so, the author comparatively analyses the constitutional responsibility of the authorities for equalizing regional differences in different countries (such as the Balkans, but also the EU member states and Switzerland).

\section{Principle of equality and regional disparity}

The principle of equality is defined as the fundamental value of the $\mathrm{EU}^{1}$ and the highest value of the constitutional order of democratic states. In democracies, people are usually equal before the law, rights and courts, and in their human rights. However, it is indisputable that the aforementioned equations are not sufficient for the existence of a just society. Therefore, for the existence of a just society, in addition to the previously mentioned forms of equality, other

${ }^{1}$ Consolidated versions of the Treaty on European Union and the Treaty on the Functioning of the European Union, Article 2, Official Journal of the European Union, C 202/1, 07.6.2016, available at: https://eurlex.europa.eu/legalcontent/EN/TXT/PDF/?uri=CELEX:12016E/TXT\&from=EN, accessed on 07.06.2021. 
forms of equality are important, especially: equality of developed (rich) and less developed (poor) areas and citizens living in them, as equality of living conditions in all parts of the state.

Regional disparities present multiple problems and consequences in a particular territorial community. This applies in particular to: a) the impact of regional disparities on hindering the implementation of fundamental values and principles (human rights, democracy, peace etc.), b) unequal position of citizens as a result of regional disparities (leading to economic and social inequality of citizens, putting them in an unequal position and neglect); c) contradiction of regional disparities with existing theories (European concept of good governance, fundamental task of public authority to establish the well-being of all citizens, efficiency of public authority, responsibility to the community as a whole, sufficient needs of European regions, equal opportunities in human rights and development, concept uniformity of living conditions, the principle of economic, social and territorial cohesion, sustainable development and care for future generations, d) economic problems (reduction of economic growth); e) political problems (reduced influence on political decision-making and conflicts between rich and poor, hindering the realization of democracy). Conflict between different authorities can also cause the development of a region to lag behind; f) social problems (reduction of social capital and emigration from underdeveloped areas). Due to a permanent underdevelopment of a certain area in socio-economic development within the wider territorialpolitical unit, its inhabitants are leaving. The population, in particular, leaves rural areas and goes to economically developed areas (especially cities) or other countries. Regional disparities also result in negative phenomena: poverty, dependence, environmental problems, the departure of the population from underdeveloped parts of the territory etc.

Zvonimir Lauc points to various causes of regional disparities. They may be the result of long-term handicaps imposed by geographical distance or social and economic change, or a combination of both. The impact of these shortcomings is often seen in social deprivation, poor quality of education, higher unemployment and inadequate infrastructure. In the case of some EU countries, part of the handicap is a legacy of their former centrally planned economic systems. (Lauc, 2011, p. 438). Possible causes of regional differences may include the following: climate (as a factor influencing human resources), cultural heritage (e.g. resistance to change), colonial exploitation and more recently neo-colonialism, the distribution of available natural resources, and geographical location and surroundings. One of the main causes of regional differences is irresponsible and inefficient government. For example, funds for regional development can be used to build fountains in the squares of European capitals, and not, for example, to irrigate rural areas.

It is an indisputable fact that regional disparities are a reason for the responsibility and actions of public authorities in the direction of their 
equalization. Therefore, individual states in their constitutions prescribe the responsibility of authorities, which is discussed alter in the paper.

\section{Role of the constitution in addressing regional disparities}

According to Branko Smerdel, "The constitution is the fundamental and highest legal act of the state. It has the greatest, supra-legal force and therefore all legal regulations within the legal system must be harmonized with it, as well as the procedures of all state bodies and bodies exercising public authority. At the same time, the constitution is the most important strategic political act, which establishes the principles of development: the political, economic and legal system. Although it strives for stability, the modern constitution has the function of directing the dynamics of sustainable development of society and therefore overlooks the way to change and adapt to the demands of development." (Smerdel, 2013, p. 3) The starting point for building any constitutional and political system must be the needs of the people, and the goal of the system is to optimally meet those needs. These needs should be equally met throughout the territory of a given state. This puts before the constitution the task of finding methods of cognition of these needs and ways of satisfying them. The constitution should express what the people, according to political leaders, desire the most, so it should be adapted to the needs and problems. It is indisputable that the people want a balanced development and cohesion of all parts of the state.

Arsen Bačić emphasizes that "the assessment of the importance of each constitutional order requires, first of all, the identification of the main problems." According to the same author, "Examples include, among other things, conflicts between different territorial communities in the country, the source of which may be: significant differences that exist in their approach to wealth, or political control." (Bačić, 2009, p. 657) Tensions and conflicts between different regions, i.e. states, can occur due to regional disparities in economic development and concentration of material wealth. The highest national authorities are responsible for balanced territorial development and cohesion, through the adoption and application of regulations.

The constitution should serve the interests of the majority (the people) against the arbitrariness of a small and powerful holders of power. Certain functions of the constitution support the realization of balanced regional development and cohesion, as is explained below.

The basic function of the constitution is to limit power. The constitution should certainly limit the government in terms of favouring and dominating certain areas while marginalizing others in order to achieve a fair territorial balance. The aspiration of a certain territorial unit for domination within the wider political community certainly poses a danger to a balanced development of an 
entire territory. The pursuit of domination within a particular political community is a danger to a balanced development of an entire territory.

Reducing economic and social disparities facilitates the effective exercise of citizens' rights. The role of the constitution is to achieve equality of people in dignity and rights in all areas of the state territory. The constitution should enable all citizens, regardless of their place of residence, the right to equal enjoyment of the common heritage of mankind, equal opportunities for the realization of human rights and equal opportunities for development.

The purpose of the constitution is to establish (constitute) the state, and thus to establish an effective territorial organization. Political-territorial organization is the foundation of a state system at subnational levels. Through the system of government organization, the constitution, by applying the principle of separation of powers, enables mutual supervision of the highest public authorities. (Smerdel, 2013, p. 4) This refers not only to a horizontal division of power (legislative, executive and judicial) but also to a vertical / territorial division of power and territorial organization. Regional organization, for example, is an important component of framework for managing regional development policy and largely determines the solutions regulated in constitutions, European law and regional development laws. However, federal constitutions also pay some attention to territory. Thus, for example, Article 29 of the Federal Constitution of Germany allows for territorial reorganization, primarily for the purposes of effective fulfilment of competencies of states.

Given that the constitution is a means of protecting the poor and powerless against the rich and powerful, this also applies to underdeveloped and poor areas that are underdeveloped, and whose inhabitants have to live with the consequences of underdevelopment every day.

Some constitutions confirm the obligation of public authorities to directly apply legal regulations of the European Union. This also applies to the area of cohesion / regional policy.

The purpose of the constitution is to achieve social and economic development of a territorial-political community. Namely, the development of a global society is not possible without a balanced development of regional subsystems as parts of a global society. The development of a society and a national economy is inconceivable without a balanced development of the centre and its peripheries.

In addition to conflicts of interest between private and public interest in the conduct of public affairs, there are also conflicts of interest between territorialpolitical units (e.g. conflicts between states, federal units and regions). The aim of the constitutional provisions is, among other things, to resolve conflicts of interest. In this regard, Branko Smerdel emphasizes the following: "All national 
communities, as well as states themselves, are based on interests, not on altruism and love, so the strong dominate in them, and the weak rely on the law." (Smerdel, 2011, p. 6015) The strong are generally more economically developed, and the weaker are poorer. Territorial imbalances result in conflicts, i.e. conflicts of interest between rich (economically stronger) and poorer (economically weaker) territorial units. In a political process, certain interests may prevail over others. This may relate, for example, to the distribution of funds between territorial units. In most countries, regional interests are present, which are especially expressed in resolving territorial, minority, cultural and other differences. Regional disparities result in conflicts, i.e. conflicts of interest between rich (economically stronger) and poorer (economically weaker) territorial units. This may relate, for example, to the distribution of funds between territorial units. The problem of balanced territorial development becomes much more politically complex if we are talking about multinational states and states with concentrated minorities in certain regions. This problem is especially evident if minority nations and their regions (which are more economically developed than others) participate more in state financing than other regions on the principle of financial equalization and solidarity, as is the case in Spain (Basque Country and Catalonia) or Belgium (Flanders). (Sadiković, 2012, p. 173)

The most general legal rule of a democratic state governed by the rule of law is that all laws and other regulations must be in accordance with the constitution and the norm derived from it according to which the constitution is directly applicable. Naturally, there are some constitutional provisions that must be defined by law. The responsibility of public authorities, which is determined by constitutional norms, is, as a rule, suable. For the purposes of protecting regional interests, i.e. the implementation of constitutional norms, a certain territorial unit may initiate a constitutional complaint against the state, i.e. the responsible state institution for non-implementation of a constitutional guarantee for a balanced development of the entire national territory.

\section{A comparative overview of constitutional responsibility of the government to reduce regional disparities}

The existence of problems and consequences, especially those related to the coexistence of people within a territorial - political community, is one of the basic conditions for the responsibility of government institutions. Therefore, a comparative overview of constitutional responsibility will be given for the following:

- the newly formed states established after the disintegration of the former Yugoslavia,

- certain Western European EU Member States, and

- Switzerland. 
In the process of constitutionalization and democratization, the national government and its apparatus become accountable to the public for the general interest. In this regard, Solomon makes it known that the countries of the Western constitutional-democratic circle are today engaged in a wide range of activities in order to achieve the greatest possible social wealth. Therefore, they are responsible to the citizens, in whose name the national institutions in a democratic state were created. (Solomon, 2009, p. 820) It follows that the responsibility of the authorities is a crucial issue of constitutional law.

One of the causes of the disintegration of the former Socialist Republic of Yugoslavia may be related to uneven development. The Federal Fund for the Development of Underdeveloped Republics and the Autonomous Province of Kosovo functioned from 1966 to 1989. Historically, in the former Yugoslav federation, Slovenia, together with the Republic of Croatia and Vojvodina, have experienced their own economic situation in circumstances of giving more to the community than receiving from the community. The mentioned developed republics with the Autonomous Province of Vojvodina could show the size of the overflow of their funds through the funds for the development of the less developed territories and through the Federal budget. The less developed republics (Serbia, Kosovo, Macedonia, Bosnia and Herzegovina and Montenegro) could not directly and continuously statistically show that, through the single market, are contributing more than they received through funds and the Federal budget. Slovenia was the first among the former Yugoslav republics to adopt a law promoting balanced regional development in $1975 .{ }^{2}$ Regarding the EU membership, Slovenia has been a full member of the EU for 17 years, and in 2013, the Republic of Croatia also became a full member. For the other former Yugoslav republics, the European future is rather uncertain, and one of the conditions for faster European integration coming from Brussels is regional co-operation, but it is still at a low level - especially when it comes to Serbia and Bosnia and Herzegovina.

Similar to individual nation states and at EU level, the requirements for the harmonization of regional disparities are expressed in the Treaty on the Functioning of the European Union, in Article 174, where the Treaty requires the action of the European Union in the harmonization of regional disparities, in the following provisions: 1) "In order to promote overall harmonious development, the Union shall develop and implement its actions leading to the strengthening of economic, social and territorial cohesion" (Article 174, paragraph 1) and 2) "In particular, the Union shall aim at reducing disparities

\footnotetext{
${ }^{2}$ Law on the promotion of more harmonious regional development in the Socialist Republic of Slovenia. 1975. Official Gazette of the SRS, 29, pp. 1491-1493, translated by the author
} 
between the levels of development of the various regions and the backwardness of the least favoured regions" (Article 174, paragraph 2). ${ }^{3}$

\subsection{Republic of Croatia}

Constitutional requirements aimed at the action of public authorities in order to equalize regional disparities emanate from:

1) the will of the people expressed in the Foundations of the Constitution of the Republic of Croatia (promotion of economic and cultural development and social welfare of citizens),

2) constitutional responsibilities of the state for the development of all its regions (Article 49, paragraph 3 of the Constitution),

3 ) constitutional responsibilities of the state for areas of interest to the Republic of Croatia and areas of special state concern (Article 52 of the Constitution),

4) constitutional responsibilities of the state for assistance to weaker units of local self-government (Article 138 of the Constitution),

5) the constitutional responsibilities of the Republic of Croatia for the implementation of the objectives and rights of the European Union (Article 143, paragraph 1 of the Constitution). ${ }^{4}$

According to the National Classification of Statistical Regions 2021, the Republic of Croatia is divided into the following level 2 statistical regions: Pannonian Croatia, Adriatic Croatia, Northern Croatia and the City of Zagreb. ${ }^{5}$ In the context of regional disparities, the Republic of Croatia features more developed regions in north and west and underdeveloped regions in east and south.

\subsection{Slovenia}

Requirements for the responsibility of authority in the Constitution of Slovenia include:

1) demands to the Slovenian State to create opportunities for a harmonious development of society (Article 5, fourth sentence),

2) demands to the State to ensure the economic, cultural and social progress of the population in hilly and mountainous areas,

${ }^{3}$ Consolidated versions of the Treaty on European Union and the Treaty on the Functioning of the European Union, Official Journal of the European Union, C 202/1, 07.6.2016, available at: https://eur-lex.europa.eu/legalcontent/EN/TXT/PDF/?uri=CELEX:12016E/TXT\&from=EN, accessed on 07.06.2021

${ }^{4}$ Constitution of the Republic of Croatia, Official Gazette, no. 85 / 10- consolidated text, 05/14, available at: https://www.zakon.hr/z/94/Ustav-RepublikeHrvatske, accessed on 07.06.2021, translated by the author

5 National Classification of Statistical Regions 2021 (HR_NUTS 2021), Official Gazette, no. 125/19, available at: https://narodnenovine.nn.hr/clanci/sluzbeni/full/2019_12_125_2507.html, accessed on 07.06.2021, translated by the author 
3) demands for providing support to municipalities due to insufficient economic development, and those municipalities that cannot fully ensure the performance of their competences. ${ }^{6}$

In Slovenia in the 1990s, there was a growth of regional development disparities, thus the redefinition of regionalization, followed by the redefinition of the regional policy, was the result of a need to solve economic, political and other problems. Slovenia treated development problems and differences in the development of urban centers on the one hand, and rural and border areas on the other, as sectorial problems instead of regional ones, which is why regional disparities continued to increase during the transition period of the 1990s.

\subsection{Northern Macedonia}

The legal basis for pursuing a policy of balanced regional development is found in Article 57 of the Constitution of Northern Macedonia, which prescribes the responsibility of the State to "encourage economic progress and care for balanced spatial and regional development and faster economic development of underdeveloped regions." In addition, in Article 41, paragraph 2, balanced development is linked to population policy, where it states: "the Republic pursues a humane population policy to ensure balanced economic and social development."7

With the adoption of the Law on Equal Regional Development of Macedonia in 2007 and its amendments of 30 December 2013 and 4 March $2014,{ }^{8}$ the Macedonian government has laid the foundations for a regional policy that meets EU standards. Until then, Macedonia lacked the entire legal framework and competent institutions to implement an effective regional policy and participate in regional and local economic development. The Law on Equal Regional Development of Northern Macedonia from $2021^{9}$ is currently in force,

${ }^{6}$ Constitution of the Republic of Slovenia (Official Gazette of the Republic of Slovenia, No. 33/91-I, 42/97 - UZS68, 66/00 - UZ80, 24/03 - UZ3a, 47, 68, 69/04 UZ14, 69/04 - UZ43, 69/04 - UZ50, 68/06 - UZ121,140,143, 47/13 - UZ148, 47/13 - UZ90,97,99, 75/16- UZ70a, and 92/21 - UZ62a), available at: http://pisrs.si/Pis.web/pregledPredpisa?id=USTA1, accessed on 07.06.2021, translated by the author

7 The Constitution of the Republic of Macedonia, Official Gazette of the Republic of Macedonia no. 52 of 22 November 1991, available at: https://www.sobranie.mk/content/Odluki\%20USTAV/UstavSRSM.pdf, accessed on 08.06.2021, translated by the author

${ }^{8}$ Law on Balanced Regional Development, Official Gazette of the Republic of Macedonia, no. 63/07, 187/13 and 43/14, available at: https://dejure.mk/zakon-izmena/zakon-za-izmenuvanje-i-dopolnuvanje-nazakonot-za-ramnomeren-regionalen-razvoj-1, accessed on 07.06.2021, translated by the author

${ }^{9}$ Local democracy in "the former Yugoslav Republic of Macedonia", Recommendation 329 (2012), Strasbourg, 16-18 October 2012 
which regulates the goals, principles and other important issues related to regional development.

In the Report of the Congress of Local and Regional Authorities entitled "Local and Regional Democracy in Macedonia", ${ }^{10}$ a special chapter (item 4.3) is entitled: "New Regional Policy: Balanced Regional Development". Point 82 emphasizes the following: "Regional development is included in the Constitution (Article 57), and the legal framework for regional policy was created by the enactment of the Law on Equal Regional Development."

The Stabilization and Association Agreement between the EU and the Republic of Macedonia ${ }^{11}$ in Article 101 titled "Regional and local development" stipulates the following: the Parties shall strengthen cooperation on regional development, with the aim of contributing to economic development and reducing regional disparities.

Regional disparities are especially evident in the fact that the Skopje region is the most developed, almost three times more compared to the Northeast region.

\subsection{Montenegro}

The preamble of the Constitution of the Republic of Montenegro, among other things, defines the responsibility of the State for the balanced development of all regions and the establishment of social justice. Related to that, Article 140, paragraph 2, prescribes the obligation of the State to "encourage the balanced economic development of all its territories." This constitutional provision is an essential condition for economic prosperity and the realization of economic and social rights of every individual and all regions. ${ }^{12}$

In the European Parliament Resolution on the Progress Report on Montenegro for 2014, dated 2 March 2015, ${ }^{13}$ the European Parliament, in point 30, urges the Government to formulate and coordinate economic policy in order, inter alia, to reduce regional disparities.

Uneven development of Montenegro is especially reflected in the aboveaverage development of the Primorska region (Budva, Tivat, Herceg Novi,

\footnotetext{
${ }^{10}$ Local democracy in "the former Yugoslav Republic of Macedonia", Recommendation 329 (2012), Strasbourg, 16-18 October 2012

${ }^{11}$ Stabilisation and Association Agreement between the European Communities and their Member States, of the one part, and the former Yugoslav Republic of Macedonia, of the other part, 6726/01, Brussels, 26 March 2001

${ }^{12}$ Constitution of the Republic of Montenegro, Constituent Assembly of Montenegro, $(1 / 2007$ and 38/2013 - Amendments I-XVI), available at: https://www.paragraf.me/propisi-crnegore/ustav-crne-gore.html, accessed on 07.06.2021, translated by the author

${ }^{13}$ European Parliament resolution on the Progress Report on Montenegro for 2014
} (2014/2947 (RSP), 02.03.2015 
Kotor and Bar) and the Central region (especially: Podgorica and Danilovgrad) and below-average development of the Northern region (Andrijevica, Plava, Bijelo Polje, Rožaje and Šavnik).

\subsection{Serbia}

The Constitution of the Republic of Serbia paid special attention to regional development, as well as to the development of underdeveloped areas. Article 94 of the Serbian Constitution is entitled "Unification of Development". In accordance with the above article: "the Republic of Serbia shall ensure balanced and sustainable regional development, in accordance with the law."14 Article 97 of the Constitution determines the competencies of the Republic of Serbia. According to the same article, paragraph 12, among the competencies, it is stated: "Development of the Republic of Serbia, policies and measures to encourage the balanced development of certain parts of the Republic of Serbia, including the development of underdeveloped areas." Thus, with the highest legal and political atom, society has recognized regional development as a need and a priority.

Based on the aforementioned constitutional Article 94, the Regional Development of Serbia Act was adopted. This law, in Article 3, paragraph 11, prescribes that the encouragement of regional development is based, inter alia, on "the principle of equality of regional development (encouragement of faster development of underdeveloped regions, areas and units of local selfgovernment)." precondition for the implementation of an active policy of balanced regional development.

Negotiations on the Stabilization and Association Agreement between the European Union and the Republic of Serbia began in November 2005. The Agreement was signed in April 2008. Prior to its entry into force, the Agreement was ratified by Serbia and EU Member States. Serbia's ratification of the Agreement has been confirmed by the Ratification of the Stabilization and Association Agreement between the European Communities and their Member States Act, of the one part, and the Republic of Serbia, of the other part. ${ }^{16}$ The Agreement emphasises regional and local development as one of the

${ }^{14}$ Constitution of the Republic of Serbia, Official Gazette of the Republic of Serbia, no. 98/2006, available at: https://www.paragraf.rs/propisi/ustav_republike_srbije.html, accessed on 07.06.2021, translated by the author

${ }^{15}$ Law on regional development Serbia, Official Gazette RS, no. 51/09, 30/10 and $89 / 15$, available https://www.paragraf.rs/propisi/zakon_o_regionalnom_razvoju.html, accessed on 08.06.2021, translated by the author

${ }^{16}$ Law on Ratification of the Stabilization and Association Agreement between the European Communities and their Member States, of the one part, and the Republic of Serbia, of the other part, Official Gazette of the Republic of Serbia 
priority areas of cooperation between the European Union and the Republic of Serbia: "the Parties shall seek to strengthen regional and local development cooperation, with the aim of contributing to economic development and reducing regional disparities" (Article 113).

In Serbia, regional disparities are expressed by the above-average development of the Belgrade region and the Serbia-North Region, and by the below-average development of Southern Serbia, the Region of Sumadija and Western Serbia, and Eastern Serbia. The status of Belgrade as a metropolis provokes repulsion of other regions towards it and vice versa, which is a typical example for Eastern Europe. The metropolis is developing at the expense of the entire state, and citizens outside the metropolis are indignant at that. The mentality plays an important role in this case. In the former Yugoslavia, people flock en masse to metropolises, since that is where entire political and economic power is located.

\subsection{Italy}

Italy represents a regional state with strong regional autonomy. Starting from the fundamental principle of economic, political and social solidarity guaranteed by the Italian Constitution (Article 2, paragraph 2, second sentence), the responsibility of public authorities for balanced development derives from its following provisions:

1) the constitutional guarantee of the establishment of the Equalization Fund in favour of the area where the fiscal capacity per capita has been reduced (Article 119, paragraph 3);

2) the responsibility of the state for special interventions for the benefit of certain municipalities, provinces, large cities and regions in order to achieve balanced development and cohesion (Article 119, paragraph 5), and

3 ) the responsibility of the state and regions for the management of the territory (Article 117, paragraph 3). ${ }^{17}$ Article 119, paragraph 5 of the Italian Constitution is crucial for achieving the balanced development of the state territory of Italy. The aforementioned article was introduced in the constitutional text in 1948, and was later modified and supplemented. Based on the aforementioned constitutional provision, the state implements special interventions and allocates special funds for the development of underdeveloped areas. State responsibility in Italy focuses on the development of backward regions, mainly through public investment, which is coordinated and financed by the central government, although there are doubts regarding its effectiveness. This means that the state can allocate funds to regions and local authorities to promote the

\footnotetext{
International Agreements, no. 83/08, available at: https://www.paragraf.rs/propisi/zakon_o_potvrdjivanju_sporazuma_o_stabili zaciji_i_pridruzivanju_izmedju_evropskih_zajednica_i_njihovih_drzava_cla nica.html, accessed on 07.06.2021, translated by the author

${ }^{17}$ Constitution of the Italian Republic, Official Gazette 27 December 1947, n. 298, available https://www.cortecostituzionale.it/documenti/download/pdf/Costituzione_del la_Repubblica_italiana.pdf, accessed on 07.06.2021, translated by the author
} 
development of this economic and social balance, but also for other purposes, which would contribute to the normal exercise of their competences.

Italy is certainly the most famous example of an EU member state with pronounced regional disparities. Since its inception, i.e. unification in 1861, this country has recorded huge regional disparities between the developed north and the backward south. Disparities between the industrialized northwest and the south has largely deepened throughout history, especially in the period between the two world wars when the northwest industrial triangle was fully formed and developed.

\subsection{Spain}

Spain, as a multinational state, i.e. a state with concentrated minorities in certain regions, is an example of a state where the problem of equalizing regional disparities is much more politically complex. The requirements for equalizing regional disparities in the Spanish Constitution relate to the following:

1) the constitutional requirement to promote economic progress and ensure a dignified life for all (preamble);

2) the constitutional requirement aimed at the responsibility of public authorities for social and economic progress and a fairer distribution of income (Article 40, paragraph 1);

3) the constitutional requirement for the action of public authorities in equalizing the standard of living of all Spaniards (Article 130, paragraph 1);

4) the constitutional requirement for the action of the State on the planning of balance and harmonization of regional and sectorial development (Article 131, paragraph 1);

5) the request for action by the State to ensure a fair balance between the different parts of Spanish territory, on the basis of solidarity (Article 138, paragraph 1);

6) the constitutional guarantee of the minimum level of basic public services throughout the entire Spanish territory and the obligation to establish the Fund in order to correct the development disparity (Article 158, paragraph 1), and

7) financial autonomy of the autonomous community in order to develop and exercise its competencies (Article 156, paragraph 1). ${ }^{18}$

Regional disparities in Spain range from Extremadura, as the least developed region, to Madrid, as the most developed region.

${ }^{18}$ Spanish Constitution, Approved by the Cortes in plenary sessions of the Congress of Deputies and the Senate held on October 31, 1978, Ratified by the Spanish people in a referendum of December 6, 1978, Sanctioned by His Majesty the King before the Cortes on 27 December 1978, available at: https://www.boe.es/buscar/act.php?id=BOE-A-1978-31229, accessed on 07.06.2021, translated by the author 


\subsection{Federal Republic of Germany}

The responsibility of public authorities for the balanced development of the national territory is also expressed in the following constitutional provisions:

1) the responsibility of the Federal State for the establishment of equal living conditions throughout the federal territory through the enactment of laws (Article 72, paragraph 2);

2) the responsibility of the Federal State and states to improve living conditions through joint efforts to improve the regional economic structure (Article 91a); 3) the responsibility of the Federal State for the uniqueness of living conditions throughout the federal territory through the distribution of taxes (Article 106, paragraph 3, item 1);

4) responsibility for financial equalization between the Federal State and states in such a way that financial strengths of different countries are adequately compensated by law, taking into account their financial strengths and needs (Article 107, paragraph 2, sentence 1). ${ }^{19}$

Germany suffered for decades from the traumas of World War II and the division of the country into two parts: the West and the East. To this day, there are numerous reminders of the differences between the "eastern" and "western" parts of Germany (e.g., lifestyles, wealth, political beliefs, etc.). The economy of the eastern part of Germany is struggling to recover, and much of the funds continue to accumulate from the west.

Germany's economic success over the previous forty years, to build a new Germany from the ruins of World War II with a level playing field, can be attributed primarily to: the German population, constitutional provisions, federal structure, responsibilities of government institutions and polycentric urban network. The application of the principle of equality of living conditions throughout the country, in political practice, has led to the fact that the supply of public goods from roads through schools to cultural institutions in all countries is almost equal. This has also led to the Federal Republic of Germany being desirable for the life and work of many foreigners. Due to the lack of labour force, the immigration of the population from less developed European and other countries started. The monthly report for German regional policy states: "In terms of gross domestic product per capita, the degree of regional disparities in Germany has narrowed in recent years and is now at the European average. Without an effective regional policy, this would not be possible."20

${ }^{19}$ Basic Law for the Federal Republic of Germany of May 23, 1949 (Federal Law Gazette p. 1), last amended by Articles 1 and 2 sentence 2 of the law of September 29, 2020 (Federal Law Gazette I, p. 2048), available at: https://www.gesetze-im-internet.de/gg/BJNR000010949.html, accessed on 07.06.2021, translated by the author

${ }^{20}$ Regional economic policy All-German approach to promoting structurally weak regions from July 1, 2014, available at: http://www.bmwi.de/Dateien/BMWi/PDF/Monatsbericht/Auszuege/05- 


\subsection{Switzerland}

The Swiss Constitution prescribes the responsibility of government institutions for balanced development and cohesion. The constitutional principle of balanced economic development is also expressed in Article 100 (economic policy), paragraphs 1 and 2 of the Swiss Constitution, which states:

1) the federal state takes measures for balanced economic development, especially to prevent unemployment and inflation;

2) the federal state takes into account the economic development of individual regions in the country and acts together with the cantons and the economy. Article 103 of the Swiss Constitution, entitled "Structural Policy", prescribes the constitutional responsibility of the Confederation for the support of regions in economic problems. The article states: "The Confederation may support regions of the country that are under economic threat and promote specific economic sectors and professions, if reasonable self-help measures are insufficient to ensure their existence. In exercising its powers under this Article, it may if necessary depart from the principle of economic freedom." 21 Switzerland's regional policy is regulated by law. Pursuant to the aforementioned constitutional article 103, the 2006 Federal Act on Swiss Regional Policy was adopted. ${ }^{22}$ "Equalisation of financial resources and burdens" is defined in Article 135 of the Swiss Constitution, according to which:

1) The Confederation regulates by law the financial equalization of burdens between the Confederation and the cantons and between the cantons,

2) The equalisation of financial resources and burdens is intended in particular to:

- reduce the differences in financial capacity among the Cantons;

- guarantee the Cantons a minimum level of financial resources;

- compensate for excessive financial burdens on individual Cantons due to geotopographical or socio-demographic factors;

- encourage inter-cantonal cooperation on burden equalisation;

- maintain the tax competitiveness of the Cantons by national and international comparison.

2014-regionale-

wirtschaftspolitik,property=pdf,bereich=bmwi2012, sprache=de,rwb=true.pdf , accessed on 07.06.2021, translated by the author

${ }^{21}$ Federal Constitution of the Swiss Confederation of 18 April 1999 (Status as of 1 January 2021), available at: https://fedlex.data.admin.ch/filestore/fedlex.data.admin.ch/eli/cc/1999/404/2 0210101/en/pdf-a/fedlex-data-admin-ch-eli-cc-1999-404-20210101-en-pdfa.pdf, accessed on 07.06.2021, translated by the author

${ }^{22}$ Federal Law on Regional Policy of October 6, 2006, The Federal Assembly of the Swiss Confederation, based on Article 103 of the Federal Constitution, SR 101, available at: https://www.fedlex.admin.ch/eli/cc/2007/136/de, accessed on 08.06 .2021 , translated by the author 
Pursuant to Article 135 of the Swiss Constitution, the Federal Act on Financing and Balancing of Burdens (FILAG) ${ }^{23}$ has been enacted. Article 1 prescribes the purpose of this Act:

-equalizing the potential and resources of rich cantons and the Federal Government in favour of the resources of poor cantons,

-geographical and topographical and socio-demographic burdens of equalization by the federal government,

- intercantonal cooperation on burden equalization.

Regional disparities are present in Switzerland also, but to significantly lower degree. Traditionally, Zurich is the most developed region, while Eastern Switzerland is the least developed region of Switzerland. Looking at the cantons, the most developed canton is Basel-Stadt in the region of Northwestern Switzerland, while Uri in Central Switzerland is the least developed canton.

\section{Conclusion}

The problem of regional disparities is not only a problem of backwards regions, it is rather a problem of states and a European problem, and ultimately it is a global problem. Backward regions represent a harmful social phenomenon in the territorial-political community and lead to social, economic, political, social and other consequences. The most important cause of regional disparities is the irresponsibility and inefficiency of public authorities. In addition to making fundamental democratic values impossible, regional disparities run counter to a number of democratic principles, theories and assumptions. It can be stated with certainty that regional disparities negatively affect: a) political system (citizens' distrust in the political system, desire for secession of certain political communities etc.), b) economic system (hindering overall economic development) and c) legal system (confirming injustice, preventing realization of fundamental democratic values, in particular the existence of unequal opportunities for the realization of human rights).

Although the principle of equality has several aspects in the basic documents, the existence of a just society certainly requires equality in other areas, such as equality of living conditions of citizens in all parts within a national territory.

Certain functions of the constitution contribute to the realization of the concept of equal development (the role of the constitution in limiting power and preventing the dominant position of certain political communities in relation to others, in creating equal opportunities for human rights, in establishing effective territorial organization, in protecting the poor, application of EU legal

\footnotetext{
${ }^{23}$ Federal Act on Financial and Burden Equalization (FiLaG) of October 3, 2003 (as of January 1, 2020), available at: https://www.fedlex.admin.ch/eli/cc/2005/225/de, accessed on 07.06.2021, translated by the author
} 
regulations, the development function of the constitution, the role of the constitution in resolving conflicts of interest and conflicts, and the role of the constitution in promoting the common good and the establishment of justice).

Requirements for the action of public authorities aimed at reducing regional disparities are expressed in the constitutions of different countries and the Treaty on the Functioning of the European Union. As for the constitutional responsibility, in most cases, it refers to the responsibility of the State in terms of equalizing the development of the entire national territory. However, every constitutional norm comes to life only after its implementation. Therefore, science cannot and must not be satisfied only with the answer to the question of what a constitutional norm should be, without the answer to the question of what a constitutional norm really is, i.e., what the effectiveness of a constitutional norm is.

Based on a comparative analysis, it can be concluded that the Federal Republic of Germany and Switzerland have the best ratio of responsibility and efficiency. Germany, despite being destroyed in a war and being divided into East and West Germany, managed to significantly reduce the disparities between the federal units. Although more than 20 years have passed since the unification, the territorial disparities are still decreasing. Germany is a good example, especially for transitional countries. The example of the Federal Republic of Germany and Switzerland shows that the federal system is considered the best political solution for territories inhabited by peoples of different economic development. The federal system is the most suitable solution for the sufficient development of all parts of a country. The federal principle is a means of maintaining overall unity, while the constituents are allowed a high degree of autonomy in certain areas of government.

On the other hand, an example of government inefficiency is Italy as a country that has failed to reduce regional disparities (between the North and the South) for many years.

All three hypotheses set forth in the introduction of the paper are considered confirmed.

H1: Although cohesion policy at the EU level aims at reducing regional disparities through shared competences between Member States and the EU, some Member States also express constitutional requirements for equalizing regional disparities.

Constitutional requirements for equalization of regional disparities, except in EU Member States (the Republic of Croatia, Italy, Spain, Federal Republic of Germany and Slovenia), but in EU candidate states (Northern Macedonia, Montenegro and Serbia), are also found in some other European Union Member States not mentioned in this paper (such as in Portugal, Bulgaria and Romania). 
$\mathrm{H} 2$ : Constitutional basis of the government's responsibility for equalizing regional disparities exists in different countries, regardless of their government system:

- in centralized unitary states (the Republic of Croatia, Slovenia, Northern Macedonia, Montenegro and Serbia),

- in decentralized unitary states (Italy and Spain), and

- federal states (Federal Republic of Germany and Switzerland).

H3. Effectiveness of public authorities in terms of equal development and living conditions within a national territory shows significant differences from state to state. These differences are visible in the Federal Republic of Germany and Switzerland (most effective) and in Croatia, Italy, Spain, Slovenia, Northern Macedonia, Montenegro and Serbia (less effective).

\section{References}

Bačić, A. (2009) Ustavne promjene i dileme konstitucionalizma, Zbornik radova Pravnog fakulteta u Splitu, god. 46, br. 4, p. 649-666

Basic Law for the Federal Republic of Germany of May 23, 1949 (Federal Law Gazette p. 1), last amended by Articles 1 and 2 sentence 2 of the law of September 29, 2020 (Federal Law Gazette I, p. 2048), available at: https://www.gesetze-im-internet.de/gg/BJNR000010949.html, accessed on 07.06.2021

Consolidated versions of the Treaty on European Union and the Treaty on the Functioning of the European Union, Article 2, Official Journal of the European Union, C 202/1, 07.6.2016, available at: https://eurlex.europa.eu/legalcontent/EN/TXT/PDF/?uri=CELEX:12016E/TXT\&from=EN, accessed on 07.06.2021

Consolidated versions of the Treaty on European Union and the Treaty on the Functioning of the European Union, Official Journal of the European Union, C 202/1, 07.6.2016, available at: https://eurlex.europa.eu/legalcontent/EN/TXT/PDF/?uri=CELEX:12016E/TXT\&from=EN, accessed on 07.06.2021

Constitution of the Italian Republic, Official Gazette 27 December 1947, n. 298 , available

at: https://www.cortecostituzionale.it/documenti/download/pdf/Costituzi one_della_Repubblica_italiana.pdf, accessed on 07.06.2021

Constitution of the Republic of Croatia, Official Gazette, no. 85 / 10consolidated text, 05/14, available at: https://www.zakon.hr/z/94/Ustav-Republike-Hrvatske, accessed on 07.06.2021

Constitution of the Republic of Montenegro, Constituent Assembly of Montenegro, (1/2007 and 38/2013 - Amendments I-XVI), available at: https://www.paragraf.me/propisi-crnegore/ustav-crne-gore.html, accessed on 07.06.2021 
Constitution of the Republic of Serbia, Official Gazette of the Republic of Serbia, no. 98/2006, available at: https://www.paragraf.rs/propisi/ustav_republike_srbije.html, accessed on 07.06 .2021

Constitution of the Republic of Slovenia (Official Gazette of the Republic of Slovenia, No. 33/91-I, 42/97 - UZS68, 66/00 - UZ80, 24/03 - UZ3a, 47, 68, 69/04 - UZ14, 69/04 - UZ43, 69/04 - UZ50, 68/06 UZ121,140,143, 47/13 - UZ148, 47/13 - UZ90,97,99, 75/16- UZ70a, and $92 / 21-\quad$ UZ62a), available at: http://pisrs.si/Pis.web/pregledPredpisa?id=USTA1, accessed on 07.06.2021

European Parliament resolution on the Progress Report on Montenegro for 2014 (2014/2947 (RSP), 02.03.2015

Federal Act on Financial and Burden Equalization (FiLaG) of October 3, 2003 (as of January 1, 2020), available at: https://www.fedlex.admin.ch/eli/cc/2005/225/de, accessed on 07.06.2021

Federal Constitution of the Swiss Confederation of 18 April 1999 (Status as of 1 January 2021), available at: https://fedlex.data.admin.ch/filestore/fedlex.data.admin.ch/eli/cc/1999 /404/20210101/en/pdf-a/fedlex-data-admin-ch-eli-cc-1999-40420210101-en-pdf-a.pdf, accessed on 07.06.2021

Federal Law on Regional Policy of October 6, 2006, The Federal Assembly of the Swiss Confederation, based on Article 103 of the Federal Constitution, SR 101, available at: https://www.fedlex.admin.ch/eli/cc/2007/136/de, accessed on 08.06.2021

Lauc, Z. (2011), Dobra vladavina na regionalnoj razini, u Zborniku radova Pravni aspekti prekogranične suradnje i EU integracija: Mađarska Hrvatska, Pećuh-Osijek, p. 415-441

Law on Balanced Regional Development, Official Gazette of the Republic of Macedonia, no. 63/07, 187/13 and 43/14, available at: https://dejure.mk/zakon-izmena/zakon-za-izmenuvanje-idopolnuvanje-na-zakonot-za-ramnomeren-regionalen-razvoj-1, accessed on 07.06.2021

Law on Balanced Regional Development, Official Gazette of the Republic of Macedonia no. 24/21, available at: https://dejure.mk/zakon/zakon-zaramnomeren-regionalen-razvoj, accessed on 05.06.2021

Law on Ratification of the Stabilization and Association Agreement between the European Communities and their Member States, of the one part, and the Republic of Serbia, of the other part, Official Gazette of the Republic of Serbia - International Agreements", no. 83/08, available at: https://www.paragraf.rs/propisi/zakon_o_potvrdjivanju_sporazuma_o _stabilizaciji_i_pridruzivanju_izmedju_evropskih_zajednica_i_njihov ih_drzava_clanica.html, accessed on 07.06.2021 
Law on regional development Serbia, Official Gazette RS, no. 51/09, 30/10 and 89/15, available at: https://www.paragraf.rs/propisi/zakon_o_regionalnom_razvoju.html, accessed on 08.06.2021

Law on the promotion of more harmonious regional development in the Socialist Republic of Slovenia. 1975. Official Gazette of the SRS, 29, pp. 1491-1493

Local democracy in "the former Yugoslav Republic of Macedonia", Recommendation 329 (2012), Strasbourg, 16-18 October 2012

National Classification of Statistical Regions 2021 (HR_NUTS 2021), Official Gazette, no. 125/19, available at: https://narodnenovine.nn.hr/clanci/sluzbeni/full/2019_12_125_2507.html, accessed on 07.06 .2021

Regional economic policy All-German approach to promoting structurally weak regions from July 1, 2014, available at: http://www.bmwi.de/Dateien/BMWi/PDF/Monatsbericht/Auszuege/0 5-2014-regionale-

wirtschaftspolitik,property $=$ pdf, bereich $=$ bmwi2012, sprache $=\mathrm{de}, \mathrm{rwb}=\mathrm{t}$ rue.pdf, accessed on 07.06.2021

Sadiković, E. (2012). Federalizam u Europi, Sarajevski žurnal za društvena pitanja, p. $165-178$

Smerdel, B. (2011), Hrvatska ustavnost u Europskoj uniji, Informator, p. 6015 $-6016$

Smerdel, B. (2013), Ustavno uređenje europske Hrvatske, Narodne novine, Zagreb, 2013

Solomon, J. M. (2009), Law and Governance in the 21st Centuri Regulatory State, 86 Texas Law Review, p. 819-856

Spanish Constitution, Approved by the Cortes in plenary sessions of the Congress of Deputies and the Senate held on October 31, 1978, Ratified by the Spanish people in a referendum of December 6, 1978, Sanctioned by His Majesty the King before the Cortes on 27 December 1978, available at: https://www.boe.es/buscar/act.php?id=BOE-A1978-31229, accessed on 07.06.2021

Stabilisation and Association Agreement between the European Communities and their Member States, of the one part, and the former Yugoslav Republic of Macedonia, of the other part, 6726/01, Brussels, 26 March 2001

The Constitution of the Republic of Macedonia, Official Gazette of the Republic of Macedonia no. 52 of 22 November 1991, available at: https://www.sobranie.mk/content/Odluki\%20USTAV/UstavSRSM.pd $\mathrm{f}$, accessed on 08.06.2021 